\title{
Przedsiębiorczość społeczna w czasie pandemii COVID-19
}

Przedsiębiorczość społeczna przejawia się między innymi podejmowanie inicjatyw oddolnych powodowanymi motywami pro-społecznymi. W czasach kryzysu tego typu działania pojawiają się spontanicznie w odpowiedzi na dostrzeżone problemy.

We współczesnym świecie kryzysy są nieuniknione i dotyczą wielu aspektów funkcjonowania społeczeństw, organizacji, państw i regionów. Mogą mieć charakter ekonomiczny, ekologiczny, społeczny, polityczny itd. W niniejszym zaproszeniu do przesyłania tekstów traktujemy kryzys szeroko: zarówno jako zjawisko dotyczące całego społeczeństwa, jak i poszczególnych grup czy też pojedynczych osób. Ostatni przykład jaki mamy to pandemia COVID-19, ale i w przeszłości w różnych częściach świata również występowały epidemie wywołane wirusami, np. grypy H1N1 (tzw. hiszpanka) w 1918-1919 r. i A/H1N1 w 2009 r., SARS w 2002-2004, itp. Ograniczenia pojawiające się w takich sytuacjach, zarówno te narzucone prawnie, jak i wynikające z samej istoty kryzysu, mobilizują do podjęcia działań solidarnościowych. Przyjmują one różne formy tymczasowego radzenia sobie w okresach trudnych dla funkcjonowania społeczeństwa.

Przyczyny sytuacji kryzysowej między innymi takie jak: ograniczanie produkcji i usług, zmniejszenie zapotrzebowania rynku na produkty i usługi, trudności spłaty kredytów, itp. prowadzą do szeregu konsekwencji zmieniających dotychczasowe relacje funkcjonalne (Zioło, 2013). Menedżerowie zmieniają wtedy hierarchię ważności dla swoich celach strategicznych (Romanowska, 2016). W sytuacjach kryzysowych, przedsiębiorcy, występując w roli agentów zmian i realizując swoją misję społeczną, podejmują się innowacyjnych, nieszablonowych działań (Kaufman i in., 2007, 2015). W okresie kryzysu zmieniają się wartości, co może wpływać na solidarność wewnątrzspołeczną i międzypokoleniową (Bartkowski, 2014) i na formy samopomocy społecznej (Augustyniak i in., 2020). Proponowane rozwiązania często są odpowiedzią na zawiłość (wicked) problemów kryzysowych (Sienkiewicz-Małyjurek, 2015). Przedsiębiorcy sięgają po nowe rozwiązania technologiczne (np. druk 3D), wykorzystując komunikację zdalną (Tarkowski, 2020). Jednakże dostrzec można ryzyko krótkotrwałości tych rozwiązań (por. „Kryzysowa integracja społeczna to tylko zryw" (Wilczyńska, 2020).

Niniejszy numer tematyczny dedykujemy zarówno mikro inicjatywom obywatelskim, jak i szerszym akcjom społecznym pojawiających się w czasach kryzysu wywołanych przez pandemie i inne klęski żywiołowe. Artykuły zawarte w tym tomie kompleksowo odnoszą się do problematyki przedsiębiorczości, ujmując ją zarówno od strony społecznej, publicznej, jak i akademickiej. W rezultacie został stworzony zbiór publikacji stanowiący fundament do czerpania 
wiedzy na temat przedsiębiorczości, jak i poszukiwania inspiracji naukowych w tym obszarze badawczym.

W pierwszym tekście dr Anna Urbaniak omawia wpływ pandemii COVID-19 na badania społeczne dotyczące starości i starzenia się. Pokazuje wpływ ograniczeń wynikających np. z lockdownu na realizację badań będących w różnych fazach rozwoju.

W drugim tekście prof. PŚ dr hab. Katarzyna Sienkiewicz-Małyjurek skoncentrowała się na omówieniu powiązań i relacji między odpornością a przedsiębiorczością w zarządzaniu kryzysowym. Ukazane interakcje między tymi koncepcjami pozwalają spojrzeć na pandemię koronawirusa jako katalizatory przedsiębiorczych zachowań.

W trzecim tekście prof. UEK dr hab. Magdalena Zdun przedstawia autorską propozycję typologii przedsiębiorczości pozwalającą wytłumaczyć zachowania przedsiębiorcze w czasach pandemii SARS-CoV-19. Upatruje w tzw. przedsiębiorczości relacyjnej szansę na uspołecznienie działań gospodarczych, uwzględniającą aspekty ekonomiczne i moralne.

W kolejnym, czwartym opracowaniu, dr Karolina Szymańska ukazuje przykłady orientacji na zdrowie człowieka jako motywatory do podjęcia działań w innych obszarach gospodarowania. Autorka stwierdza, że kryzys może pełnić funkcję także stymulującą dla poszukiwania innowacyjnych rozwiązań, w której dostrzega się zróżnicowanie potrzeb klienta i identyfikacja nowej dla niego wartości.

W piątym tekście prof. prof. UŁ Danuta Stawasz i Dorota Sikora-Fernandez przedstawiają kapitał społeczny w sytuacjach kryzysowych. W szczególności odnoszą swoje rozważania do organizacji pozarządowych. W wyniku rozważań zwracają uwagę na słabość współpracy na linii „władze publiczne-organizacje pozarządowe” co daje asumpt do badania jakości kapitału społecznego.

W szóstym opracowaniu prof. PŚ dr hab. Izabela Jonek-Kowalska przedstawiła rozwój podmiotów ekonomii społecznej (PES) z uwzględnieniem ich finansowania. Wnioski z analizy wskazują na nadchodzące trudności w pozyskaniu finansowania działalności PES w szczególności wynikające z kryzysu związanego z pandemią COVID-19.

W siódmym tekście prof. UP Agnieszka Ziomek i Oleysa Radilova przedstawiają analizę potencjału konkurencyjnego małych organizacji pozarządowych z obszaru sztuki i kultury. W tym celu wykorzystują model 5 sił autorstwa M. Portera i na jego kanwie wskazują wpływ finansowania na utrzymanie działalności tychże organizacji.

W następnym, ósmym opracowaniu, dr Paulina Ledwoń charakteryzuje niektóre z krajowych i unijnym rozwiązań prawnych ukierunkowanych na rozwój mikroprzedsiębiorczości, uzasadniając konieczność interwencjonizmu w takich sytuacjach kryzysowych jak pandemia COVID-19.

W dziewiątym tekście zamieszczonym w niniejszym tomie dr Adam Drozdek omawia kontrolę podatkową i celno-skarbową z perspektywy regulacji prawnych przyjętych do przeciwdziałania pandemii COVID-19. Wskazując na różnice miedzy tymi dwoma rodzajami kontroli, Autor negatywnie ocenia związek tzw. ustaw covidowych z realizacją tych czynności kontrolnych.

W przedostatnim, dziesiątym opracowaniu, dr inż. Karolina Wielicka-Gańczarczyk podjęła badania nad przenikaniem się podejść definicyjnych przedsiębiorczości ze szczególnym uwzględnieniem przedsiębiorczości publicznej. Wynik analizy wykazał wielowymiarowość tego terminu wraz z istniejącymi próbami dookreślenia i węższego ujęcia.

W ostatnim tekście autorstwa dr Renaty Winkler i Wioletty Karnej przedstawiono wyniki badań nad strukturą budżetu czasu studiujących kobiet w latach 2017-2020 w dwóch krajach: 
Polsce i Ukrainie. Autorki wykazują, że przemiany społeczne mają wpływ na strukturę czasu pracy.

Jak redaktorzy tomu poświęconego przedsiębiorczości społecznej w czasach kryzysu wyrażamy nadzieję, że zebrane teksty ukazują podjęty temat z kilku uzupełniających się perspektyw. Dotyczy to zarówno pierwszych tekstów wprowadzających, jak i kolejnych poświęconych wpływom pandemii COVID-19 na działanie przedsiębiorstw społecznych.

Marek Ćwiklicki, Katarzyna Sienkiewicz-Małyjurek

Redaktorzy

\section{Literatura}

Augustyniak, P., Ciesiołkiewicz, K., Dudkiewicz, I., Fandrejewska, A., Gąciarz, B., Obracht-Prondzyński, C., Pacut, A., Przedlacki, M., Sadzik, J., Tarkowski, A., \& Wygnański, K. (2020). Alert Społeczny 1: Ratujmy najsłabszych, bądźmy wspólnotą ( $\mathrm{Nr}$ 1; Open Eyes Economy Summit). https://oees.pl/wp-content/uploads/2020/04/ Alert-Spo\%C5\%82eczny-1-OEES.pdf

Bartkowski, J. (2014). Solidarność społeczna i kryzys: Zmiany wartości w Europie i w Polsce w warunkach kryzysu. Acta Universitatis Lodziensis. Folia Sociologica, 48, 19-34.

Kaufman, R., Avgar, A., \& Mirsky, J. (2015). Opportunities for sustainable community development in the wake of disaster situations: Lessons from the field. International Journal of Sustainability Policy and Practice, 11(2), $1-10$.

Kaufman, R., Mirsky, J., \& Avgar, A. (2007). Social Entrepreneurship in Crisis Situations. International Journal of Diversity in Organizations, Communities and Nations, 7(3), 227-232.

Romanowska, M. (2016). The Evolution of the Strategic Goals of Polish Enterprises During the Economic Crisis. Journal of Management and Financial Sciences, 24(9), 13-26.

Sienkiewicz-Małyjurek, K. (2015). Skuteczne zarzadzanie kryzysowe. Difin.

Tarkowski, A. (2020). Społeczeństwo coraz bardziej open source'owe [Ngo.pl]. Jak COVID-19 zmieni Polskę. Prognoza liderów polskich środowisk branżowych i społecznych. https://publicystyka.ngo.pl/jak-covid-19-zmieni-polske-prognoza-liderow-polskich-srodowisk-branzowych-i-spolecznych

Wilczyńska, A. (2020). Kryzysowa integracja społeczna to tylko zryw [Ngo.pl]. Jak COVID-19 zmieni Polskę. Prognoza liderów polskich środowisk branżowych i społecznych. https://publicystyka.ngo.pl/jak-covid-19-zmieni-polske-prognoza-liderow-polskich-srodowisk-branzowych-i-spolecznych

Zioło, Z. (2013). Uwarunkowania rozwoju przedsiębiorczości w warunkach kryzysu gospodarczego. Przedsiębiorczość-Edukacja, 9, 10-33.

\section{Informacje o autorach}

\section{Marek Ćwiklicki, prof. dr hab.}

ORCID: 0000-0002-5298-0210

Katedra Zarządzania Organizacjami Publicznymi

Kolegium Gospodarki i Administracji Publicznej

Uniwersytet Ekonomiczny w Krakowie

ul. Rakowicka 27, 31-510 Kraków

e-mail: marek.cwiklicki @uek.krakow.pl
Katarzyna Sienkiewicz-Małyjurek, prof. PŚ dr hab.

ORCID: 0000-0002-0915-5776

Katedra Zarządzania i Logistyki

Wydział Organizacji i Zarządzania

Politechnika Śląska

ul. Roosevelta 26, 41-800 Zabrze

e-mail: katarzyna.sienkiewicz-malyjurek@polsı.pl 


\section{Prawa autorskie i licencja / Copyright and License}

(c) $(1) \Theta$

Publikacja na licencji Creative Commons Uznanie autorstwa Użycie niekomercyjne - Bez utworów zależnych 4.0 Międzynarodowe (CC BY-ND 4.0) http://creativecommons.org/licenses/by-nc-nd/4.0/deed/pl

This work is published under the terms of the Creative Commons

Attribution - NoDerivetives International (CC BY-ND 4.0) License http://creativecommons.org/licenses/by-nc-nd/4.0

Wydane przez Uniwersytet Ekonomiczny w Krakowie. Małopolska Szkoła Administracji Publicznej

Published by Cracow University of Economics - Krakow, Poland. Małopolska School of Public Administration of the Cracow University of Economics 